\title{
EFFECT OF PERCEPTION OF QUALITY, PRICE, ITS REPUTATION AND CUSTOMER SATISFACTION ON PURCHASE DECISION AVIATION SERVICES (Case Study: Customer Services Flights PT. Lion Air)
}

\author{
Oleh: \\ Peran Simanihuruk, SE, M.Si
}

\begin{abstract}
Peran Simanihuruk, SE, M.Si, The purpose of this study to analyze the influence of perceived quality, price, the company's reputation and customer satisfaction partially and simultaneously to the purchase decision-making aviation services. Benefits Research, provide empirical evidence about the influence of the variables that can influence the purchasing decision of customers, and provide a solution in the form of advice to the management of these variables. For the community. providing knowledge to the community, especially for those who want to engage in the world of business and relating to the maintenance of the brand as well as maintaining the presence of the customer. For education, contributing to the academic community about the importance of managing the variables that can influence the purchasing decision of the consumer through the perception of quality, price, the company's reputation and customer satisfaction.

Total sample of 96 respondents, the method of collecting data through questioner and documentation, methods of data analysis by regression. The results of the regression equation: $P K P=$ $10.034+.018+P K 0,873 H 0,17 R P+.705 K P$. meaning that the variable perception of quality, price, the company's reputation and customer satisfaction has a positive influence on the purchase decision aviation services. Of the four variables that have more influence on the purchase decision is the variable price of aviation services. The correlation coefficient variable perception of quality, price, the company's reputation and customer satisfaction to the purchase decision aviation services have a very strong relationship with the value of $r=.743$. The coefficient of determination of $r 2=.552049$, meaning that the variable perception of quality, price, reputation and customer satisfaction Company was able to explain 55.2\% of the purchase decision-making airline, while $44.8 \%$ are influenced by other factors. Based on $t$ test, $t$ value (Price and Customer Satisfaction) $>t$ table means in partial, price and customer satisfaction has a significant influence on the purchase decision-making aviation services. While the $t$ (perception of the quality and reputation of the company) $\leq t$ partial table does not have a significant influence on the purchase decision-making aviation services. By F test, F count (variable perception of quality, price, the company's reputation and customer satisfaction) $>F$ table, meaning that simultaneous variables has a significant influence on the purchase decision aviation services.

Based on the results of the study should the company need to increase the perception of quality through improved service quality and reputation of the company through increased attributes offered through its products. Customer satisfaction and price becomes the center of attention of the customer, then the management should still be able to maintain it so that it has a very high competitiveness.
\end{abstract}

Keywords: Perception of Quality, Price, Corporate Reputation, Customer Satisfaction and Purchase Decision Making

\section{PENDAHULUAN}

Dewasa ini persaingan dunia bisnis jasa semakin ketat dengan adanya kemajuan teknologi komunikasi dan informasi sehingga konsumen mempunyai informasi yang lengkap mengenai alternatif pilihan produk/jasa yang tersedia di pasar. Para produsen atau penjual berusaha memenuhi kebutuhan dan keinginan serta memberikan kepuasan secara maksimal kepada konsumen. Freenan dan Dart dalam Puspitasari (2006) mengemukakan bahwa kinerja pelayanan yang tinggi merupakan hal yang sangat mendasar bagi kelangsungan hidup suatu perusahaan jasa. Pelayanan yang berkinerja tinggi adalah 
pelayanan yang mampu memberikan kepuasan terhadap kebutuhan pelanggan atau mampu melebihi harapan pelanggan (Anderson, Fornell, dan Lehmann, 1994).

Tujuan umum dari hubungan pemasaran adalah untuk membangun dan mempertahankan pelanggan yang dapat menguntungkan perusahaan (Zeithaml dan Bitner, 1996). Pelanggan merupakan aset yang memegang peranan penting untuk menentukan keberhasilan perusahaan. Mengingat pelanggan mampu mencerminkan potensi pertumbuhan perusahaan dimasa mendatang maka upaya untuk menciptakan dan mempertahankan pelanggan menjadi prioritas utama bagi perusahaan.

Konsep kepuasan konsumen merupakan hal penting bagi para manajer pemasaran dimana kepuasan konsumen dapat mendorong pembelian ulang (Fornell, 1992). Kepuasan konsumen merupakan aset yang penting bagi perusahaan karena dapat digunakan sebagai indikator atas kualitas dan pendapatan perusahaan dimasa mendatang. Kepuasan pelanggan merupakan hasil dari perbandingan antara harapan dan kenyataan yang diterima pelanggan setelah mengkonsumsi barang atau jasa. Berkaitan dengan kesetiaan pelanggan, Anderson, Fornell, dan Lehmann (1994) menyatakan bahwa apabila pelanggan puas terhadap barang atau kualitas layanan yang diberikan maka akan timbul kesetiaan pelanggan sehingga minat beli pelanggan meningkat dan membuat pelanggan kembali melakukan pembelian ulang (repurchase). Pelanggan yang puas disebut sebagai retained customers sedangkan pelanggan yang tidak puas adalah lost customers. Pelanggan yang bertahan (retained customers) memiliki peranan penting dalam persaingan bisnis yang ketat bagi pencapaian performa bisnis yang tinggi (Crane dalam Puspitasari, 2006). Sehingga strategi kualitas pelayanan yang mampu meningkatkan jumlah pelanggan yang bertahan (customers retained rate) menjadi fokus utama dalam era persaingan bisnis jasa yang ketat. Oleh karena itu, PT. Lion Air sebagai entitas bisnis jasa yang bergerak dalam industri jasa penerbangan sudah semestinya berorientasi kepada kualitas layanan dan kepuasan pelanggan karena pelanggan yang puas merupakan salah satu aset penting untuk kelangsungan hidup dan perkembangan bisnis itu sendiri. Pengelolaan strategi-strategi yang tepat untuk menarik pelanggan perlu direncanakan secara matang agar pelanggan mau membeli produk atau jasa yang dihasilkan oleh perusahaan. Selain itu perusahaan juga perlu untuk terus berupaya agar konsumen dapat menjadi pelanggan yang loyal.

Fenomena yang terjadi saat ini yaitu adanya perang harga (budget airline/terbang murah) dari maskapai-maskapai baru yang memperlihatkan kualitas layanannya berupa perluasan segmen. Dalam rangka meningkatkan kualitas pelayanan dan kenyamanan penumpang, PT. Lion Air telah menambah armadanya dengan pesawat-pesawat yang lebih canggih dan nyaman. Dari penelitian yang telah dilakukan memberikan respon dari pelanggan bahwa harga tiket yang cenderung mengalami peningkatan tetap mereka bayar karena tingkat kepercayaan masyarakat terhadap pelayanan jasa penerbangan PT. Lion Air yang semakin tinggi sehingga mereka merasa aman dalam melakukan perjalanan. Hal tersebut selaras dengan penelitian yang telah dilakukan oleh Brown dan Dacin (1997) dimana reputasi perusahaan sangat penting dari sudut pandang pelanggan untuk memberikan gambaran terhadap kualitas produk atau jasa yang dihasilkan, dimana harga yang tinggi dari suatu merek seringkali dipersepsikan memiliki kualitas yang tinggi (Chapman dan Wahlers, 1999). Seperti dikemukakan oleh para peneliti dalam Hellier, Geursen, Carr, dan Rickard (2003) dikatakan bahwa kepuasan pelanggan secara keseluruhan pada layanan jasa berasosiasi kuat terhadap perilaku konsumen untuk menggunakan kembali jasa dari penyedia yang sama. Zeithaml (1988) mengidentifikasikan persepsi kualitas sebagai komponen dari nilai merek dimana persepsi kualitas yang tinggi akan mengarahkan konsumen untuk memilih merek tersebut dibandingkan dengan merek pesaing.

Persepsi kualitas yang dirasakan oleh konsumen berpengaruh terhadap kesediaan konsumen tersebut untuk membeli sebuah produk (Chapman dan Wahlers, 1999). Persepsi 
kualitas jasa dengan lima dimensi kualitas jasa berhubungan positif terhadap minat beli ulang pelanggan (Li dan Lee, 2001). Parasuraman, Zeithaml, dan Berry (1985, 1988) mengemukakan bahwa terdapat hubungan positif secara langsung antara persepsi kualitas dengan minat beli ulang. Penelitian ini terfokus pada Pengaruh Persepsi Kualitas, Harga, Reputasi Perusahaan dan Kepuasan Pelanggan Terhadap Pengambilan Keputusan Pembelian Jasa Penerbangan ( Studi Kasus : Pelanggan Jasa Penerbangan PT. Lion Air).

Berdasarkan latar belakang tersebut diatas maka fenomena masalah bagaimana mempertahankan pelanggan ditengah fenomena perang harga, persepsi kualitas, reputasi perusahaan dan kepuasan pelanggan sebagai variabel pendahulunya. Maka perumusan masalah : Bagaimana Pengaruh persepsi kualitas, harga, reputasi perusahaan dan kepuasan pelanggan secara parsial dan simultan terhadap pengambilan keputusan pembelian jasa penerbangan

\section{Persepsi Kualitas}

\section{KAJIAN TEORITIS}

Persepsi kualitas (perceived quality) menurut Aaker (1997) dapat didefinisikan sebagai persepsi pelanggan terhadap keseluruhan kualitas atau keunggulan suatu produk atau jasa layanan berkaitan dengan apa yang diharapkan oleh pelanggan. Aaker menegaskan satu hal yang harus selalu diingat, yaitu bahwa persepsi kualitas merupakan persepsi para pelanggan, oleh sebab itu persepsi kualitas tidak dapat ditetapkan secara obyektif. Selain itu, persepsi pelanggan akan melibatkan apa yang penting bagi pelanggan karena setiap pelanggan memiliki kepentingan yang berbeda-beda terhadap suatu produk atau jasa.

Tjiptono (2005:40) mengatakan bahwa perceived quality merupakan penilaian pelanggan terhadap keunggulan atau superioritas produk secara keseluruhan. Oleh sebab itu, perceived quality didasarkan pada evaluasi subyektif konsumen (bukan manajer atau pakar) terhadap kualitas produk. Durianto, Sugiarto, dan Sitinjak (2004:96) mengemukakan bahwa persepsi kualitas dapat didefinisikan sebagai persepsi pelanggan terhadap keseluruhan kualitas atau keunggulan produk. Menurut Simamora dalam Pane dan Rini (2011:119) persepsi kualitas (perceived quality) yang dimaksud adalah persepsi pelanggan terhadap kualitas atau keunggulan suatu produk atau jasa layanan ditinjau dari fungsinya secara relatif dengan produk-produk lain.

Sedangkan menurut Ferrinadewi (2008:172) perceived quality adalah bagaimana keunggulan produk secara keseluruhan didasarkan pada evaluasi subyektif konsumen. Dari beberapa definisi diatas dapat disimpulkan bahwa perceived quality adalah penilaian pelanggan terhadap kualitas produk secara keseluruhan.

Maka dapat dikatakan bahwa membahas persepsi kualitas berarti akan membahas keterlibatan dan kepentingan pelanggan. Persepsi kualitas yang tinggi menunjukkan bahwa melalui penggunaan dalam jangka waktu yang panjang, konsumen memperoleh diferensiasi dan superioritas dari merek tersebut. Zeithaml mengidentifikasikan persepsi kualitas sebagai komponen dari nilai merek dimana persepsi kualitas yang tinggi akan mengarahkan konsumen untuk memilih merek tersebut dibandingkan dengan merek pesaing. Persepsi kualitas yang dirasakan oleh konsumen berpengaruh terhadap kesediaan konsumen tersebut untuk membeli sebuah produk. Ini berarti bahwa semakin tinggi nilai yang dirasakan oleh konsumen, maka akan semakin tinggi pula kesediaan konsumen tersebut untuk akhirnya membeli (Chapman dan Wahlers, 1999). Persepsi kualitas mencerminkan perasaan pelanggan yang tidak nampak dan secara menyeluruh mengenai suatu merek. Akan tetapi, biasanya persepsi kualitas didasarkan pada dimensi-dimensi yang termasuk dalam karakteristik produk tersebut dimana merek dikaitkan dengan hal-hal seperti keandalan dan kinerja. Lima dimensi kualitas jasa (Parasuraman, Zeithaml, dan Berry, 1988; Zeithaml et al, 1996) yang dipergunakan untuk memahami harapan dan persepsi konsumen terhadap kualitas jasa tersebut adalah : 
1. Keandalan (Reliability). Kemampuan untuk melaksanakan jasa yang dijanjikan dengan tepat dan terpercaya.

2. Ketanggapan (Responsiveness). Kemauan perusahaan untuk membantu pelanggan dan memberikan jasa dengan cepat.

3. Keyakinan (Assurance). Pengetahuan dan keramahtamahan para karyawan serta kemampuan mereka untuk menimbulkan kepercayaan dan keyakinan.

4. Empati (Empathy). Syarat untuk peduli, memberi perhatian pribadi bagi pelanggan.

5. Berwujud (Tangibles). Penampilan fasilitas fisik (interior dan eksterior), peralatan, karyawan, dan media komunikasi.

Berdasarkan pada penelitian-penelitian tersebut diatas maka variabel persepsi kualitas dapat dibentuk dari tiga indikator, yaitu keandalan, ketanggapan,keyakinan, empati dan berujud.

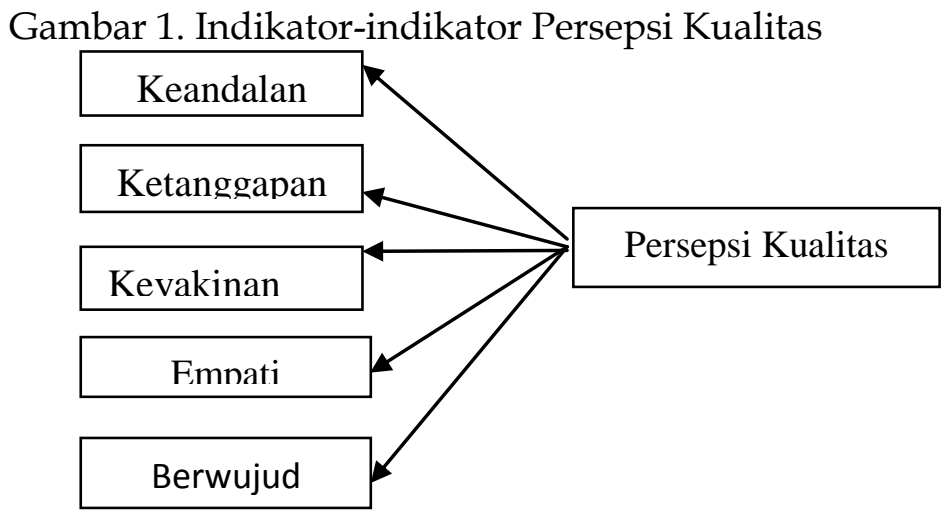

Sumber : Parasuraman et al. (1988) dan Zeithaml et al. (1996) dikembangkan dalam penelitian ini.

Terdapat lima nilai yang dapat menggambarkan nilai-nilai dari persepsi kualitas Durianto dalam Pramono (2011) yaitu sebagai berikut:

a. Alasan untuk membeli. Persepsi kualitas yang baik dapat membantu periklanan dan promosi yang dilakukan perusahaan menjadi lebih efektif, yang akan terkait dengan keputusan pembelian oleh konsumen.

b. Diferensiasi atau posisi. Persepsi kualitas suatu merek akan berpengaruh untuk menentukan posisi merek tersebut dalam persaingan.

c. Harga optimum. Penentuan harga optimum yang tepat dapat membantu perusahaan untuk meningkatkan persepsi kualitas merek tersebut.

d. Minat saluran distribusi. Pedagang akan lebih menyukai untuk memasarkan produk yang disukai oleh konsumen, dan konsumen lebih menyukai produk yang memiliki persepsi kualitas yang baik.

e. Perluasan merek. Persepsi kualitas yang kuat dapat dijadikan sebagai dasar oleh perusahaan untuk melaksanakan kebijakan perluasan merek.

\section{Harga}

Harga merupakan besarnya pengorbanan yang dilakukan oleh konsumen untuk memperoleh sebuah produk atau jasa yang dibutuhkan (Zeithaml, 1988). Stedman (2000) mengidentifikasikan bahwa harga merupakan salah satu factor penting yang dapat mempengaruhi perilaku konsumen dalam pembelian merek, karena suatu barang atau jasa pastilah mempunyai nilai. Sedangkan nilai itu sendiri didasarkan dari harga, yang merupakan tolak ukur dari barang maupun jasa yang bersangkutan. Kennedy (1994) mengemukakan bahwa penjualan produk berkualitas tinggi kemungkinan dapat ditandai berdasarkan harga yang tinggi pula. Konsumen seringkali menggunakan harga sebagai 
petunjuk ekstrinsik atau indikator dari kualitas ataupun manfaat suatu produk. Hasil dari beberapa penelitian mengemukakan bahwa harga yang tinggi dari suatu merek seringkali dipersepsikan memiliki kualitas yang tinggi dan tidak peka terhadap persaingan potongan harga seperti merek-merek dengan harga yang rendah (Yoo, Donthu, dan Lee, 2000). Harga yang tinggi dapat menimbulkan persepsi kualitas produk atau jasa yang tinggi pula dari suatu merek (Monroe, 1973 dalam Ward, Chitty, and Achard, 2005; Dodds, Grewal, dan Monroe, 1991). Dalam penelitiannya, Ward, Chitty, and Achard (2005) mengukur persepsi harga dari konsumen dengan perkiraan besarnya harga yang bersedia dibayar oleh mereka untuk tiap merek terlibat. Teknik tersebut juga digunakan oleh Al-Sabbahy, Ekinci, dan Riley (2004) menilai persepsi responden terhadap kewajaran harga yang harus dibayar beradasarkan internal feeling dan pengetahuan mereka atas harga dari penyedia jasa lainnya pada bidang yang sama.

Menurut Kotler (2001) dalam membuat keputusan mengenai harga harus memperhatikan atau harga sangat dipengaruhi oleh :

1. Konsumen sasaran. Apabila konsumen sasaran suatu perusahaan adalah konsumen tingkat atas maka perusahaan akan cenderung menetapkan harga yang tinggi.

2. Permintaan konsumen. Jika terjadi permintaan yang cukup tinggi terhadap suatu produk dan jumlah barang yang tersedia sedikit maka perusahaan cenderung menetapkan harga cukup tinggi.

3. Pesaing . Jika dalam suatu pasar terdapat banyak pesaing yang menjual produk yang sejenis, produsen akan menetapkan harga yang rendah atau bersaing.

Berdasarkan pada penelitian-penelitian tersebut diatas maka variabel harga dapat dibentuk dari tiga indikator, yaitu perkiraan harga, kesesuaian pengorbanan, dan kewajaran harga

.Gambar 2. Indikator-indikator Harga

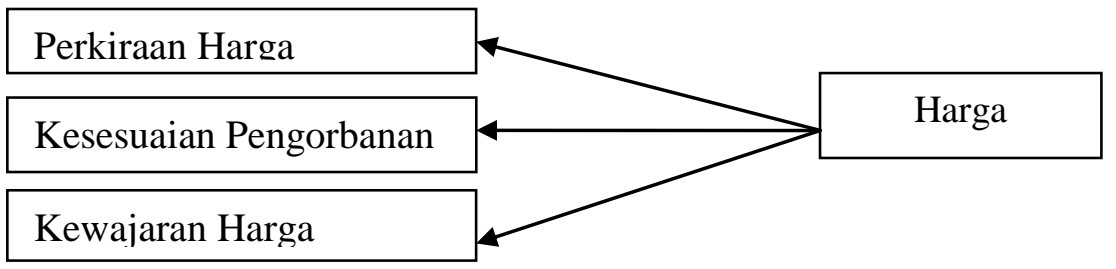

Sumber : Ward, Chitty, dan Achard (2005); Al-Sabbahy, Ekinci, dan Riley (2004);

Zeithaml (1988) dikembangkan dalam penelitian ini

\section{Reputasi Perusahaan}

Zeithaml (1988) mengemukakan bahwa kualitas yang dirasakan dari suatu produk atau jasa erat hubungannya dengan reputasi yang diasosiasikan dengan nama merek. Herbig, Milewicz dan Golden (1994) menyatakan bahwa reputasi perusahaan dapat dilihat dari kompetensi perusahaan tersebut dan keunggulan dibandingkan dengan kompetitornya. Moorman dan Minner (1997) menyatakan bahwa keberhasilan perusahaan secara maksimal dapat dicapai apabila perusahaan tersebut fokus terhadap core business, sebab hal itu akan merefleksikan core competencies yang mereka punyai.

Keahlian perusahaan tercermin dalam pengetahuan dan pengalaman perusahaan tersebut dalam industri yang dimasukinya (Brown dan Dacin, 1997; Moorman dan Miner, 1997). Menurut Brown dan Dacin (1997) reputasi perusahaan sangat penting dari sudut pandang pelanggan untuk memberikan gambaran terhadap kualitas produk atau jasa yang dihasilkan. Reputasi dari perusahaan dalam sudut pandang pelanggan dapat dijadikan jaminan bagi pelanggan untuk menilai kualitas produk atau jasa Berdasarkan pernyataanpernyataan tersebut maka variabel reputasi perusahaan dibentuk oleh tiga indikator, yaitu 
pengalaman perusahaan dalam industri yang dimasukinya, kompetensi perusahaan, dan keunggulan perusahaan dibanding kompetitor.

Gambar 3. Indikator-indikator Reputasi Perusahaan

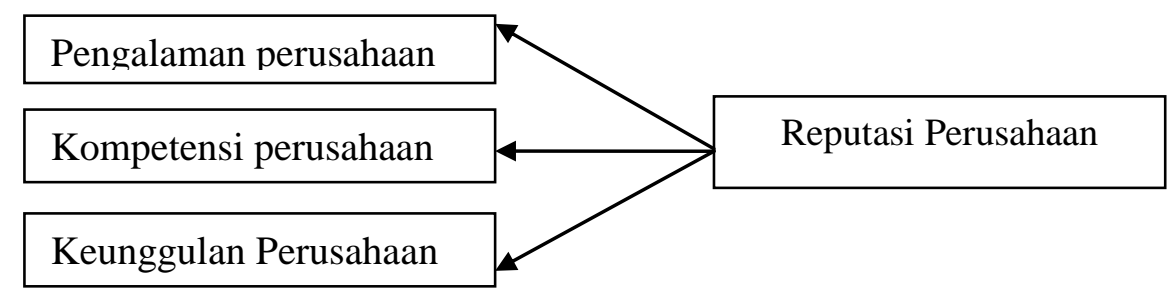

Sumber : Herbig, Milewicz dan Golden (1994); Brown dan Dacin (1997) dikembangkan dalam penelitian ini

\section{Kepuasan Pelanggan}

Menurut Kotler dan Keller (2007:177) secara umum kepuasan adalah perasaan senang atau kecewa seseorang yang muncul setelah membandingkan kinerja (hasil) produk yang dipikirkan terhadap kinerja (atau hasil) yang diharapkan. Jika kinerja berada dibawah harapan, pelanggan tidak puas. Jika kinerja memenuhi harapan, pelanggan puas. Jika kinerja melebihi harapan, pelanggan sangat puas.

Kepuasan pelanggan adalah sejauh mana manfaat sebuah produk dirasakan sesuai dengan apa yang diharapkan pelanggan (Amir dalam Tambrin, 2010:64). Sedangkan Supranto dalam Tambrin (2010:63) mendefinisikan kepuasan pelanggan merupakan label yang digunakan oleh pelanggan untuk meringkas suatu himpunan aksi atau tindakan yang terlihat, terkait dengan produk atau jasa.

Kepuasan pelanggan juga dapat dianggap sebagai evaluasi purna beli dimana alternatif yang dipilih sekurang-kurangnya memberi hasil (outcome) yang sama atau melampaui harapan pelanggan (Engel dalam Ardhani,2007:157).

Dari beberapa definisi diatas, dapat disimpulkan bahwa kepuasan pelanggan adalah hal yang dirasakan pelanggan setelah mendapatkan hasil yang dicapai dari produk atas harapan pelanggan pada produk tersebut.

Inti kepuasan merupakan suatu tingkat perasaan pelanggan yang diperoleh setelah menikmati sesuatu. Kepuasan pelanggan didefinisikan sebagai semua sikap berkenaan dengan barang atau jasa setelah diterima dan dipakai, dengan kata lain bahwa kepuasan (satisfaction) adalah pilihan setelah evaluasi penilaian dari sebuah transakasi yang spesifik (Cronin \& Taylor, 1992). Cronin dan Taylor (1994) dalam penelitiannya berhasil membuktikan bahwa kepuasan pelanggan ditentukan oleh penilaian pelanggan terhadap kualitas pelayanan yang diberikan. Kepuasan pelanggan menurut Spreng, Mackenzie \& Olshavsky (1996) akan dipengaruhi oleh harapan, persepsi kinerja, dan penilaian atas kinerja produk atau jasa yang dikonsumsi. Terdapat korelasi positif yang kuat antara persepsi kinerja terhadap kepuasan pelanggan (Anderson, Fornell, dan Lehmann, 1994; Anderson dan Sullivan, 1993). Oliver (1993) menyatakan bahwa kepuasan merupakan tingkat perasaan seseorang setelah membandingkan kinerja atau hasil yang dirasakannya dengan harapan. Tse dan Wilton (1988) menyatakan bahwa kepuasan atau ketidakpuasan pelanggan adalah merupakan respon pelanggan terhadap evaluasi ketidaksesuaian yang dirasakan antara harapan sebelumnya dan kinerja aktual produk setelah pemakaiannya. Oliver (1993) meneliti mengenai kepuasan konsumen yang menunjukkan adanya pengaruh positif antara pengalaman pembelian sebelumnya terhadap tingkat kepuasan.

Dengan adanya pengalaman terhadap pembelian sebelumnya kemungkinan hanya sedikit ketidaksesuaian antara harapan dan kinerja serta kemungkinan kecil terhadap ketidakpuasan. Berdasarkan pengalaman yang diperolehnya, pelanggan memiliki 
kecenderungan untuk membangun nilainilai ekspektasi tertentu. Nilai ekspektasi tersebut akan memberikan dampak bagi pelanggan untuk melakukan perbandingan terhadap kompetitor dari produk yang pernah dirasakannya. Secara langsung penilaian tersebut akan mempengaruhi pandangan dan penilaian pelanggan terhadap perusahaan kompetitor. Berdasarkan hal-hal tersebut maka variabel kepuasan pelanggan dapat dibentuk dari tiga indikator, yaitu kesesuaian harapan, persepsi kinerja, dan penilaian pelanggan.

Gambar 4. Indikator-indikator Kepusan Pelanggan

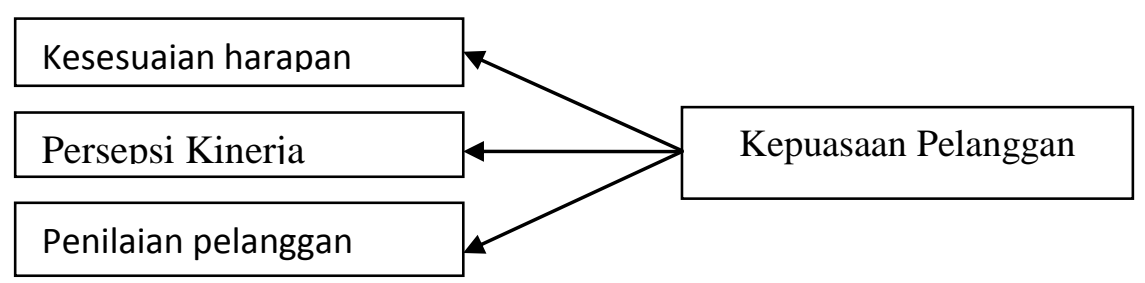

Sumber : Spreng, Mackenzie \& Olshavsky (1996) dikembangkan dalam penelitian ini

\section{Konsep Kepuasan Pelanggan}

Menurut Johnson et. al. dalam Ardhani (2007:157) terdapat dua konsep kepuasan pelanggan, seperti :

1. Transaction - specific. Konsep ini adalah konsep kepuasan yang dihasilkan dari proses penilaian setelah konsumen membeli produk tersebut. Pelanggan pasti segera mengevaluasi produk yang ia beli setelah melakukan pembelian.

2. Overall satisfaction. Konsep ini disebut juga dengan general - overall merupakan konsep kepuasan yang dihasilkan dengan evaluasi keseluruhan yang didasarkan pada pengalaman konsumen. Menjadi lebih penting karena mencerminkan kinerja masa lalu, saat ini, dan yang akan datang.

\section{Dampak Kepuasan Pelanggan}

Pelanggan dihadapkan pada dua kondisi, yaitu puas atau tidak puas. Ketika pelanggan merasa puas atau tidak puas dapat memberikan dampak bagi perusahaan. Jika pelanggan mengalami kepuasan, maka akan memberikan manfaat, seperti (Hartini,2011: 9) :

1. Hubungan antara pelanggan dan perusahaan akan menjadi harmonis.

2. Memberikan dasar yang baik bagi pembelian ulang.

3. Dapat mendorong terciptanya loyalitas.

4. Membentuk suatu rekomendasi dari mulut ke mulut yang menguntungkan perusahaan.

5. Reputasi perusahaan akan menjadi baik dimata pelanggan.

6. Laba yang diperoleh meningkat.

Menurut Schiffman dan Kanuk dalam Hartini (2011:8) dalam menyikapi ketidakpuasan ada beberapa hal yang dilakukan pelanggan, seperti :

1. Berhenti membeli produk atau jasa pada toko yang sama.

2. Negative word of mouth.

3. Mengeluh (komplain) pada penjual, agen swasta atau pemerintah.

4. Meminta ganti rugi dari penjual.

5. Melakukan penuntutan resmi untuk mendapat ganti rugi.

\section{Metode Pengukuran Kepuasan Pelanggan}

Menurut Kotler dalam Budiman (2008:146) ada empat metode yang digunakan perusahaan untuk mengukur kepuasan pelanggan, yaitu : 
1. Sistem Keluhan dan Saran. Perusahaan memberikan kesempatan seluas-luasnya kepada pelanggan untuk menyampaikan saran, pendapat, dan keluhan mereka.

2. Survei Kepuasan Pelanggan. Dilakukan melalui pos, telepon, maupun wawancara pribadi sebagai bentuk perhatian yang diberikan perusahaan kepada pelanggan untuk mendapat tanggapannya dan umpan balik secara langsung.

3. Ghost Shopping (Pembeli Bayangan). Metode ini dilakukan beberapa orang untuk berperan sebagai pelanggan produk perusahaan atau pesaing sehingga didapat laporan mengenai kelebihan dan kelemahannya.

4. Lost Customer Analysis (Analisis Kehilangan Pelanggan). Perusahan berusaha menghubungi pelanggannya yang berhenti membeli produk perusahaan. Yang diharapkan adalah memperoleh informasi penyebab terjadinya hal tersebut.

\section{Ruang Lingkup Keputusan Pembelian.}

Keputusan pembelian yang dilakukan oleh konsumen akan mencakup pertimbangan berbagai aspek. Pada umumnya konsentrasi pemasaran lebih diarahkan pada keputusan tentang pemiliihan alternative terhadap suatu merek produk tertentu. Hal ini disebabkan strategi pemasaran seringkali dikembangkan bagi pencapaian target untuk merek produk tertentu. Walaupun demikian, ini bukan berarti bahwa keputusan pembelian akan ditentukan oleh keputusan tentang merek individual saja. Harus juga diingat bahwa konsumen mengambil keputusan untuk membeli didasarkan atas suatu hierarki proses keputusan pembelian.

Dalam proses penentuan alternatif keputusan pada setiap hierarki, seorang konsumen juga akan memnentukan sumber informasi yang akan dijadikan dasar pengambilan keputusan. Beberapa sumber informasi yang dapat dipergunakan olehkonsumen antara lain; dealer, keluarga, teman, forum atau komunitas, dan media massa baik itu yang bersifat offline ataupun online. Faktanya pemahaman terhadap sumber informasi saja dirasakan belum cukup, bagi manajer pemasaran yang menjadi fokus utama dari semuanya itu adalah pada implikasi startegi pemasaran yang akan diperguanakan bagi kepentingan perusahaan.

\section{Tipe Keputusan Pembelian}

Keputusan pembelian merupakan kontinum dan memiliki dua dimensi. Dimensi pertama adalah degree, menunjukkan keterlibatan konsumen di dalam keputusan membeli yaitu dari high involvement purchase decision ke low involvement purchase decision. Dimensi kedua adalah content, menunjukkan jumlah informasi yang dibutuhkan oleh konsumen untuk dapat membuat keputusan pembelian yaitu dari decision making (mencari informasi dan mempertimbangkan berbagai alternatif merk) ke habit (sedikit membutuhkan informasi dan hanya mempertimbangkan satu merk saja). Pembuatan keputusan pembelian dapat bergerak dari pembuatan keputusan pembelian dengan keterklibatan tinggi (high involvement purchase decision) ke pembuatan keputusan pembelian dengan keterlibatan rendah (low involvement purchase decision). Konsumen akan lebih terlibat dengan suatu produk ketika produk yang akan dibeli memiliki kriteria sebagai berikut.

1. Penting bagi konsumen

2. Memiliki keterlibatan emosional

3. Secara kontinyu menarik bagi konsumen

4. Mengakibatkan resiko keuangan

Merupakan identitas yang menciptakan image khusus bagi konsumen. Dengan demikian, semakin penting dan beresiko suatu produk yang akan dibeli, konsumen semakin mempertimbangkan berbagai merk dan mencari berbagai informasi yang dibutuhkan.

a. Complex decision making. Complex decision making bisa terjadi, ketika konsumen melakukan pembelian produk yang membutuhkan berbagai pertimbangan sehubungan 
dengan pentingnya produk dan tingginya resiko bagi indvidu konsumen. Pada umumnya, konsumen akan mempertimbangkan berbagai merk dan mencari berbagai informasi yang dibutuhkan sebelum membeli rumah atau mobil, konsumen akan mempertimbangkan secara selektif setiap detai perbedaan dari masing-masing produk. Informasi ini penting bagi konsumen, supaya tidak terjadi post purchase dissonance (ketidaknyamanan setelah pembelian).

b. Limited decision making. Limited decision making terjadi ketika konsumen melakukan keputusan untuk membeli suatu produk yang membutuhkan pertimbangan merk dan informasi, yang secara kontinyu menarik bagi konsumen atau konsumen sering mengkonsumsi atau menggunakan produk tersebut. Proses pembuatan keputusan terbatas ini membutuhkan lebih sedikit informasi daripada complex decision making. Berdasar teorinya, pembelian cereal atau makanan ringan termasuk dalam limited decision making. Namun bagi konsumen yang sedang melakukan diet kalori atau konsumen yang berwawasan green product, atau natural product, mereka akan melakukan pencarian informasi yang lebih banyak untuk memutuskan pembelian produk cereal atau makanan ringan, daripada konsumen pada umumnya, sehingga pembuatan keputusannya termasuk complex.

c. Brand loyalty. Brand loyalty menunjukkan sikap loyal terhadap merk tertentu dan berdampak pada pembelian secara konsisten sepanjang waktu. Konsumen yang loyal terhadap merk tertentu akan melakukan pembelian merk tersebut dalam jangka panjang, dan membutuhkan informasi yang relatif sedikit, karena sudah menjadi kebiasaannya untuk membeli produk dengan merk tersebut. Loyalitas konsumen terhadap merk tertentu ini disebabkan oleh rasa puas atau rasa keinginan dan kebutuhan yang terpenuhi terhadap merk tersebut secara berulang-ulang sehingga menjadi kebiasaan.

d. Inertia. Ketika konsumen menggunakan hirarki low involvement, konsumen membentuk keyakinan terhadap produk secara pasif dan membuat keputusan hanya dengan memproses sedikit informasi dan selanjutnya mengevaluasi merk setelah pembelian. Jenis produk inertia antara lain garam dapur, gula, deterjen, dll. Konsumen tidak perlu pikir panjang untuk membeli garam dapur berdasarkan pengalamannya di masa lalu terhadap merk tertentu, atau merk lain yang tersedia di toko. Proses ini kadang disebut dengan spurious loyalty, karena seakan-akan konsumen loyal terhadap merk garam tersebut, namun ketika merk garam yang dimaksud tidak tersedia, konsumen akan dengan cepat beralih merk tanpa pikir panjang lagi, konsumen membeli produk itu bukan karena loyalitas pada merek tetapi keinginan untuk menghindari proses keputusan yang berbelit.

e. Impulse Purchasing. Tipe keputusan ini dikenal dengan keputusan pembelian tiba-tiba, dikatakan demikian karena konsumen tidak membutuhkan banyak pertimbangan untuk melakukan pembelian. Proses keputusan dapat dilakukan dengan cepat, tanpa harus menunggu pencarian informasi dan judgement tertentu untuk memilih produk. Bagi konsumen merek itu sendiri sudah cukup dipergunakan sebagai dasar untuk membandingkan produk. Satu hal lagi yang perlu diingat tipe keputusan ini adalah bahwa konsumen realtif tidak menghadapi switching cost (biaya yang timbul atas peralihan keproduk lain) yang tinggi.

\section{Proses Pengambilan Keputusan Konsumen.}

Schiffman dan Kanuk (1994) mendefinisikan suatu keputusan sebagai pemilihan suatu tindakan dari dua atau lebih pilihan alternatif. Pada saat konsumen membeli sebuah produk, umumnya konsumen mengikuti suatu proses atau tahapan dalam pengambilan keputusan. Menurut Engel et al. (1994:31-32) dan Lamb et al. (2001:188), ada lima tahapan yaitu :

1. Pengenalan Kebutuhan, 
2. Pencarian Informasi,

3. Evaluasi Alternatif,

4. Keputusan Pembelian,

5. Perilaku Pascapembelian.

Gambar 5. Proses Pengambilan Keputusan Konsumen

\section{Proses Keputusan Pembelian}

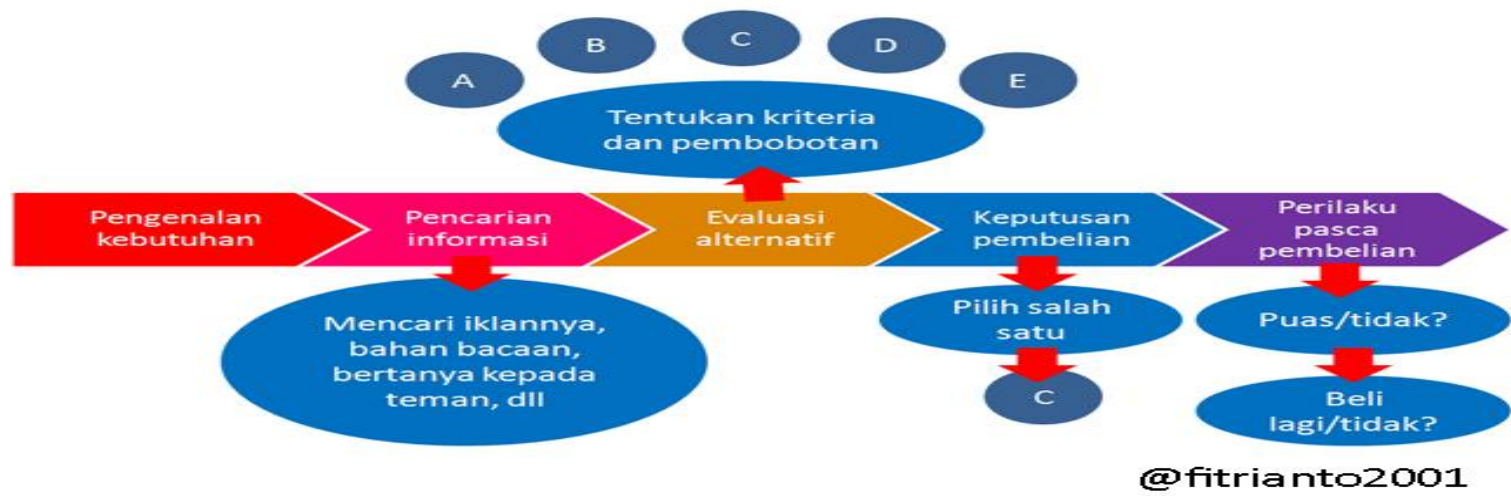

Keterangan :

1. Pengenalan Kebutuhan. Proses pembelian oleh konsumen diawali sejak pembeli mengenali kebutuhan atau masalah. Kebutuhan tersebut dapat ditimbulkan oleh rangsangan internal atau eksternal. Rangsangan internal, terjadi pada salah satu kebutuhan umum seseorang (seperti lapar dan haus) telah mencapai ambang batas tertentu dan mulai menjadi pendorong. Sedangkan rangsangan eksternal, salah satunya terjadi karena seseorang menonton iklan atau melihat produk baru milik tetangganya.

2. Pencarian Informasi. Setelah konsumen yang terangsang kebutuhannya, konsumen akan terdorong untuk mencari informasi yang lebih banyak. Orang lebih peka terhadap informasi produk. Selanjutnya, orang mulai aktif mencari informasi: bertanya kepada teman, mendatangi toko untuk mencari tahu atau membuka-buka internet untuk membandingkan spesifisikasi dan harga barang.

3. Evaluasi Alternatif. Evaluasi umunya mencerminkan keyakinan dan sikap yang mempengaruhi perilaku pembelian mereka. Keyakinan (belief) adalah gambaran pemikiran yang dianut seseorang tentang gambaran sesuatu. Keyakinan seseorang tentang produk atau merek mempengaruhi keputusan pembelian mereka. Yang tak kalah pentingnya dengan keyakinan adalah sikap. Sikap (attitude) adalah evaluasi, perasaan emosi, dan kecenderungan tindakan yang menguntungkan atau tidak menguntungkan dan bertahan lama pada sesorang pada objek atau gagasan tertentu (Kotler dan Keller, 2007).

4. Keputusan Pembelian. Dalam suatu kasus pembelian, konsumen bisa mengambil beberapa sub keputusan, meliputi merk, pemasok, jumlah, waktu pelaksanaan dan metode pembayaran. untuk produk-produk yang komplek akan membutuhkan pertimbangan yang pajang sebelum memutuskan pembelian, sedangkan untuk produkproduk yang sederhana seperti kebutuhan sehari-hari konsumen cenderung lebih mudah memutuskan untuk pembelian. Pada fase ini perusahaan harus sebisa mungkin memudahkan konsumen untuk dapat mengakuisisi produk yang di inginkan, seperti kemudahan memperoleh produk kemudahan untuk melakukan pembayaran, kemudahan untuk dapat konsultasi lebih lanjut. Implikasi strategi pemasaran: Perusahaan dapat mempercepat atau merangsang konsumen dengan memberikan promo-promo menarik agar konsumen segera mengakuisisi pembeliannya. Seperti 
pemberian potongan harga, pemberian jumlah tertenu, program bonus, program bundling dsb, bahkan perusahaan juga dapat memfasilitasi bagi konsumen yang ingin melakukan pembelian dengan metode kredit.

5. Perilaku Pasca Pembelian. Setelah pembelian dilakukan, konsumen akan selalu siaga terhadap informasi yang mendukung keputusannya. Konsumen akan membanding kan produk yang telah ia beli, dengan produk lain. Hal ini dikarenakan konsumen mengalami ketidakcocokan dengan fasilitas-fasilitas tertentu pada barang yang telah ia beli, atau mendengar keunggulan tentang merek lain. Pada fase ini anda akan memberikan respon atau feedback atas produk yang telah dibeli, apakah anda puas atau tidak puas. Banyak respon yang terjadi seperti anda bisa memberikan rekomendasi ke kerabat atau keluarga anda, atau bahkan bila anda sangat puas atas produk pilihan anda maka anda menjadi loyal terhadap produk ataupun merek produk tersebut. Implikasi strategi pemasaran: Perusahaan dapat merespon dengan memberikan pelayanan purna jual, memberikan instruksi atas produk yang dibelinya, atau memberikan garansi yang yang sesuai atas produknya.

\section{Kerangka Pemikiran Teoritis}

Berdasarkan telaah pustaka dan hipotesis yang dikembangkan diatas maka sebuah model untuk penelitian ini dapat dikembangkan seperti pada gambar 5 Model tersebut terdiri dari variabel harga, reputasi perusahaan, kepuasan pelanggan, persepsi kualitas, dan minat beli ulang. Untuk mengukur variabelvariabel tersebut, sasaran penelitian ini adalah konsumen (end user) dari obyek penelitian melalui pengisian kuisioner dengan skala interval $1-5$.

Gambar 6. Kerangka Pemikiran Teoritis

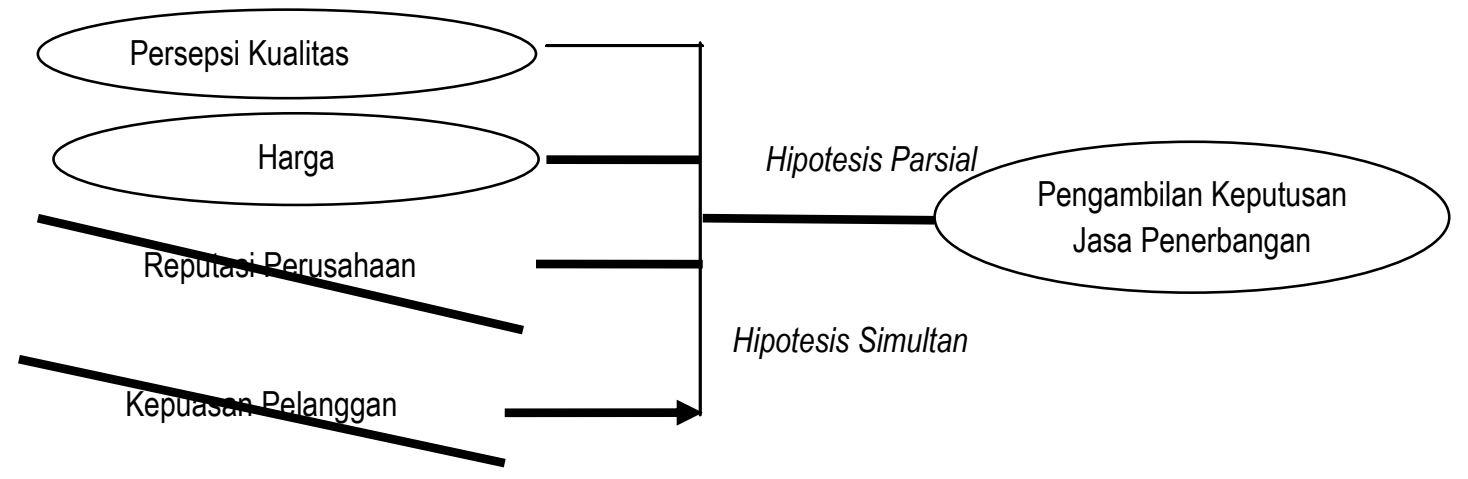

Sumber : Dikembangkan untuk penelitian ini METODE PENELITIAN

\section{Populasi dan Sampel}

Populasi dalam suatu penelitian merupakan kumpulan individu atau obyek yang merupakan sifat-sifat umum. Arikunto (2010: 173) menjelaskan bahwa "populasi adalah keseluruhan subjek penelitian."Sedangkan menurut Sugiyono (2010 : 80) populasi adalah "wilayah generalisasi yang terdiri atas obyek atau subyek yang mempunyai kualitas dan karakteristik tertentu yang ditetapkan oleh peneliti untuk dipelajari dan kemudian ditarik kesimpulannya." Populasi pada penelitian ini adalah seluruh pelanggan jasa penerbangan PT. Lion Air.

Penarikan atau pembuatan sampel dari populasi untuk mewakili populasi disebabkan untuk mengangkat kesimpulan penelitian sebagai suatu yang berlaku bagi populasi. Arikunto (2010: 174) mengatakan bahwa "sampel adalah sebagian atau wakil populasi yang diteliti." Selanjutnya menurut Sugiyono (2010:81) sampel adalah "bagian dari jumlah dan karakteristik yang dimiliki oleh populasi tersebut." Dalam penelitian ini penulis 
mengambil sampel dengan menggunakan teknik purposive sampling. Mengenai hal ini, Arikunto (2010:183) menjelaskan bahwa "purposive sampling dilakukan dengan cara mengambil subjek bukan didasarkan atas strata, random atau daerah tetapi didasarkan atas adanya tujuan tertentu." Begitu pula menurut Sugiyono (2010:85) sampling purposive adalah "teknik penentuan sampel dengan pertimbangan tertentu." Artinya setiap subjek yang diambil dari populasi dipilih dengan sengaja berdasarkan tujuan dan pertimbangan tertentu. Tujuan dan pertimbangan pengambilan subjek/sampel penelitian ini adalah sampel tersebut menguasai keterampilan dalam permainan. Berdasarkan tingkat keyakinan $95 \%\left(\alpha=5 \%, Z^{1} / 2 \alpha=1,96\right)$, kesalahan maksimum $(\varepsilon)=0,1$ dan standar deviasi $(\sigma)=0,5$ maka rumus penentuan sampel (Supranto, 2001: 113):

$$
\begin{aligned}
n & =\left(\frac{Z_{\alpha / 2}{ }^{2} \times \sigma}{\varepsilon}\right)^{2} \\
& =\left(\frac{1,96 \times 0,5}{0,1}\right)^{2} \\
& =96,04 \text { orang }
\end{aligned}
$$

Dalam penelitian ini, maka jumlah sampel yang dibutuhkan $(n)=96,04$ dibulatkan menjadi 96 orang. Teknik penentuan sampel dilakukan secara purposive sampling.

\section{Operasionalisasi Variabel}

\begin{tabular}{|c|c|c|c|}
\hline Variabel & Definisi Operasional & Indikator & Pengukuran \\
\hline $\begin{array}{l}\text { Persepsi } \\
\text { Kualitas }\end{array}$ & $\begin{array}{l}\text { Persepsi pelanggan terhadap } \\
\text { keseluruhan kualitas atau } \\
\text { keunggulan suatu produk } \\
\text { atau jasa layanan berkaitan } \\
\text { dengan apa yang diharapkan } \\
\text { oleh pelanggan }\end{array}$ & $\begin{array}{l}\text { Keandalan } \\
\text { Ketanggapan } \\
\text { Keyakinan } \\
\text { Empati } \\
\text { Berwujud }\end{array}$ & $\begin{array}{l}\text { Diukur dengan } \\
\text { skala setuju - } \\
\text { tidak setuju, } \\
\text { range poin } \\
\text { penilaian } 1 \text { - } 5\end{array}$ \\
\hline Harga & $\begin{array}{l}\text { Suatu pengorbanan yang di } \\
\text { persepsikan oleh konsumen } \\
\text { sebagai biaya untuk } \\
\text { memperoleh sejumlah barang } \\
\text { atau jasa yang } \\
\text { dibutuhkan }\end{array}$ & $\begin{array}{l}\text { Perkiraan harga } \\
\text { Kesesuaian } \\
\text { Pengorbanan } \\
\text { Kewajaran harga }\end{array}$ & $\begin{array}{l}\text { Diukur dengan } \\
\text { skala setuju - } \\
\text { tidak setuju, } \\
\text { range poin } \\
\text { penilaian } 1 \text { - } 5\end{array}$ \\
\hline $\begin{array}{l}\text { Reputasi } \\
\text { Perusahaan }\end{array}$ & $\begin{array}{l}\text { Kepercayaan konsumen atas } \\
\text { nama baik dari penyedia jasa }\end{array}$ & $\begin{array}{l}\text { Pengalaman } \\
\text { perusahaan } \\
\text { Kompetensi } \\
\text { perusahaan } \\
\text { Keunggulan } \\
\text { perusahaan }\end{array}$ & $\begin{array}{l}\text { Diukur dengan } \\
\text { skala setuju - } \\
\text { tidak setuju, } \\
\text { range poin } \\
\text { penilaian } 1 \text { - } 5\end{array}$ \\
\hline $\begin{array}{l}\text { Kepuasan } \\
\text { Pelanggan }\end{array}$ & $\begin{array}{l}\text { Tingkat kepuasan konsumen } \\
\text { terhadap pengalaman } \\
\text { melakukan konsumsi suatu } \\
\text { produk atau jasa yang } \\
\text { diperoleh dari kemampuan } \\
\text { penyedia untuk memenuhi } \\
\text { harapan dan kebutuhan } \\
\text { pelanggan }\end{array}$ & $\begin{array}{l}\text { Kesesuaian harapan } \\
\text { Persepsi kinerja } \\
\text { Penilaian pelanggan }\end{array}$ & $\begin{array}{l}\text { Diukur dengan } \\
\text { skala setuju - } \\
\text { tidak setuju, } \\
\text { range poin } \\
\text { penilaian } 1 \text { - } 5\end{array}$ \\
\hline $\begin{array}{l}\text { Keputusan } \\
\text { Pembelian } \\
\end{array}$ & $\begin{array}{l}\text { Tahapan-tahapan yang } \\
\text { dilakukan konsumen sebelum }\end{array}$ & $\begin{array}{l}\text { Pengenalan } \\
\text { Kebutuhan, }\end{array}$ & $\begin{array}{l}\text { Diukur dengan } \\
\text { skala setuju - }\end{array}$ \\
\hline
\end{tabular}

Defenisi operasionalisasi variabel yang diteliti dapat dilihat pada tabel berikut:

Tabel 1. Definisi Operasional Variabel 


\begin{tabular}{|l|l|l|l|}
\hline Ulang & melakukan pembelian & Pencarian Informasi, & tidak setuju, \\
& terhadap suatu produk. & Evaluasi Alternatif, & Keputusan \\
& & Pembelian, & penilaian 1 - 5 \\
& & Perilaku & \\
& & Pascapembelian. & \\
\hline
\end{tabular}

Sumber : Dikembangkan untuk penelitian ini.

\section{Teknik Pengumpulan Data}

Pada penelitian ini digunakan metode pengumpulan data primer melalui metode survei yang terdiri dari wawancara dan kuisioner sebagai berikut :

1. Wawancara. Wawancara merupakan teknik pengumpulan data dalam metode survei yang menggunakan pertanyaan secara lisan kepada subyek penelitian.

2. Koeisioner. Koesioner merupakan metode pengumpulan data yang diperoleh dari jawaban yang diberikan responden berdasarkan daftar pertanyaan yang telah disusun sebelumnya. Pada penelitian ini digunakan kuisioner dengan skala Likert dimana pernyataan-pernyataan dalam kuisioner dibuat dengan nilai 1 sampai dengan 5 untuk mewakili pendapat responden seperti sangat tidak puas sampai dengan sangat puas.

\section{Metode Analisis}

Teknik analisis data regresi linier berganda (multiple regression analysis) (Sugiyono, 2005). bertujuan untuk mencari pengaruh variabel bebas terhadap variabel terikatnya. Maka persamaan regresi linier berganda dapat dirumuskan sebagai berikut :

$\mathrm{Y}=\beta_{0}+\beta_{1} \mathrm{X} 1+\beta_{2} \mathrm{X} 2+\beta_{3} \mathrm{X} 3+\beta_{0} \mathrm{X} 4+\mathrm{ei}$

Keterangan :

$\mathrm{Y}=$ Variabel Terikat, $\mathrm{X} 1, \mathrm{X} 2$ dan $\mathrm{X} 3=$ Variabel Bebas, ei $=$ Kesalahan dalam estimasi, bo $=$ Konstanta, b1,b2,b3, b4 = Koefisien Regresi.

Persamaan regresi linier berganda tersebut diaplikasikan untuk melihat pengaruh persepsi kualitas, harga, reputasi perusahaan dan kepuasan pelanggan terhadap pengambilan keputusan pembelian jasa penerbangan yang diaplikasikan, dengan rumus:

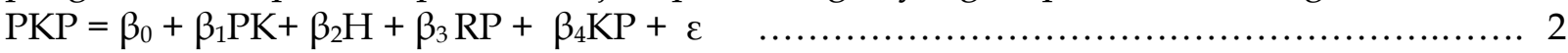
Keterangan : PKP = Pengambilan Keputusan Pembelian, PK = Persepsi Kualitas, $\mathrm{H}=$ Harga, RP $=$ Reputasi Perusahaan, $\mathrm{KP}=$ Kepuasan Pelanggan, $\beta_{0}=$ Konstanta, $\varepsilon=$ Tingkat kesalahan estimasi dan $\beta_{1} \beta_{2} \beta_{3} \beta_{4}=$ Koefisien regresi

Untuk membuktikan apakah hipotesis digunakan uji $\mathrm{F}$ dan $\mathrm{t}$.

\section{A. Uji F}

1. $\mathrm{H}_{0}: \beta \mathrm{i}=0$, artinya persepsi kualitas, harga, reputasi perusahaan dan kepuasan pelanggan tidak berpengaruh signifikan secara simultan terhadap pengambilan keputusan pembelian jasa penerbangan.

$\mathrm{H}_{1}: \beta \mathrm{i} \neq 0$, artinya persepsi kualitas, harga, reputasi perusahaan dan kepuasan pelanggan berpengaruh signifikan secara simultan terhadap pengambilan keputusan pembelian jasa penerbangan.

2. Tingkat Keyakinan $95 \%$ dengan Jumlah sampel $=96$ responden

Level of significan $(\alpha)=5 \%$

3. Uji statistik F:

$$
F=\frac{R^{2} /[k-1]}{\left[1-R^{2}\right] /(n-k)}
$$

Keterangan: $\mathrm{k}=$ Jumlah variabel, $\mathrm{R}^{2}=$ koefisien determinan, $\mathrm{n}=$ Jumlah sampel

4. Kriteria pengujian: $\mathrm{H}_{0}$ diterima jika $\mathrm{F}_{\text {hitung }} \leq \mathrm{F}$ tabel 
$\mathrm{H}_{1}$ diterima jika $\mathrm{F}_{\text {hitung }}>\mathrm{F}_{\text {tabel }}$

5.Kesimpulan : Dengan membandingkan langkah 3 dan 4 untuk menerima atau menolak hipotesis.

B. Uji t

1. $\mathrm{H}_{0}: \beta \mathrm{i}=0$, artinya persepsi kualitas, harga, reputasi perusahaan dan kepuasan pelanggan tidak berpengaruh signifikan secara parsial terhadap pengambilan keputusan pembelian jasa penerbangan.

$\mathrm{H}_{1}: \beta i \neq 0$, artinya persepsi kualitas, harga, reputasi perusahaan dan kepuasan pelanggan berpengaruh signifikan secara parsial terhadap pengambilan keputusan pembelian jasa penerbangan.

2. Tingkat Keyakinan $95 \%$ dan Jumlah sampel $=96$ responden

3. Uji statistik $\mathrm{t}$ :

$$
t=\frac{\beta s-\beta}{S . E[\beta s]}
$$

Keterangan: $t=t_{\text {hitung, }}, \beta_{\mathrm{S}}=$ koefisien regresi, S.E[ $[\beta \mathrm{i}]=$ Standar error koefisien regresi

4. Kriteria pengujian:

$\mathrm{H}_{0}$ diterima jika $-\mathrm{t}_{\alpha / 2}: \mathrm{dk} \leq \mathrm{t}_{\text {hitung }} \leq \mathrm{t}_{\alpha / 2}: \mathrm{dk}$

$\mathrm{H}_{1}$ diterima jika $\mathrm{t}_{\text {hitung }}>\mathrm{t}_{\alpha / 2}$ : $\mathrm{dk}$ atau $\mathrm{t}_{\text {hitung }}<-\mathrm{t}_{\alpha / 2}: \mathrm{dk}$

5.. Kesimpulan : Dengan membandingkan langkah 3 dan 4 untuk menerima atau menolak hipotesis.

\section{HASIL PENELITIAN DAN PEMBAHASAN}

\section{Gambaran Umum Fakultas Ekonomi Universitas Katolik Santo Thomas Sumatera Utara}

Fakultas Ekonomi Universitas Katolik Santo Thomas Sumatera Utara merupakan pengembangan dari Akademi Sekretaris dan Manajemen (ASM) Katolik Budi Murni yang berdiri mulai 16 Mei 1980, dengan surat izin operasional dari Kopertis Wilayah I Nomor: 066/PP/KOP.I/1982. Selanjutnya pada tahun 1984, ASM Katolik Budi Murni memperoleh status terdaftar dari Menteri Pendidikan dan Kebudayaan RI Nomor: 069/0/1984. Kemudian Keuskupan Agusng Medan mengembangkan ASM Katolik Budi Murni menjadi Fakultas Ekonomi Universitas Katolik Santo Thomas Sumatera Utara dengan surat persetujuan Kopertis Wilayah I Nomor: 091/SK/KOP.I/1984 pada tanggal 23 April 1984, yang berlokasi di Jl. Jend. S. Parman 107 Medan. Pada tahap ini Fakultas Ekonomi terdiri dari Jurusan Manajemen Perkantoran Program Studi D3, Jurusan Program Studi Manajemen S1 dan Jurusan Akuntansi S1.

Pada tahun 1986, Jurusan Manajemen Program Studi S1 dan Jurusan Akuntansi Program Studi S1 memperoleh status terdaftar dengan SK Meneteri Pendidikan dan Kebudayaan RI Nomor: 0387/0/1986 dan jurusan Manajemen Program Studi Manajemen Perkantoran Program D3 memperoleh status diakui dengan SK Menteri Pendidikan dan Kebudayaan Nomor: 006/0/1990 tanggal 4 Januari 1990. Sejak tahun 1984 sampai dengan 1992, Fakultas Ekonomi menempati di Jl. Jend. S. Parman 107, Medan dengan jumlah mahasiswa sekitar 2.600 orang. Sehubungan dengan perkembangan jumlah mahasiswa, pada tahun 1993, Universitas Katolik Santo Thomas Sumatera Utara mendirikan kampus baru Fakultas Ekonomi di Jl. Setiabudi Tanjung Sari. Kampus baru Fakultas Ekonomi terdiri dari bangunan berlantai tiga dengan daya tampung yang lebih besar.

Visi pendirian Fakultas Ekonomi Universitas Katolik Santo Thomas Sumatera Utara Medan adalah terselenggaranya pendidikan ilmu ekonomi yang berlandaskan ajaran dan moral Katolik untuk menghasilkan lulusan yang berintegritas tinggi dan sanggup mengabdikan diri bagi negara, bangsa dan masyarakat. Misinya adalah: 
1. Mewujudkan penyelenggaraan pendidikan akademi dan profesional di bidang ilmu ekonomi yang berkualitas tinggi yang berlandaskan keimanan, kejujursan, ketaqwaan dan wawasan kebangsaan.

2. Mewujudkan penyelenggaraan penelitian dan pengembangan ilmu ekonomi untuk menjawab tantangan dan kebutuhan masyarakat, dan

3. Menyelenggarakan tugas-tugas pengabdian pada masyarakat sebagai penerapan ilmu ekonomi.

Sasaran Fakultas Ekonomi Universitas Katolik Santo Thomas Sumatera Utara Medan adalah:

1. Membentuk Sarjana Ekonomi dan Ahli Madya yang memiliki kemampuan dan keterampilan manajerial yang berkualitas berlandaskan ajaran dan moral luhur.

2. Membentuk Sarjana Ekonomi dan Ahli Madya yang memiliki ilmu pengetahuan yang komprehensif di bidang ilmu ekonomi dan dapat diterima di pasar kerja.

3. Membentuk Sarjana Ekonomi dan Ahli Madya dengan tingkat prestasi yang memuaskan dan mempunyai daya saing yang tinggi.

Pengaruh persepsi kualitas, harga, reputasi perusahaan dan kepuasan pelanggan terhadap pengambilan keputusan pembelian jasa penerbangan

Berdasarkan teknik analisis yang digunakan dengan persamaan Regresi Berganda untuk melihat pengaruh variabel persepsi kualitas, harga, reputasi perusahaan dan kepuasan pelanggan terhadap pengambilan keputusan pembelian jasa penerbangan menunjukkan hasil sebagai berikut:

Tabel 2. Coefficientsa variabel persepsi kualitas, harga, reputasi perusahaan dan kepuasan pelanggan terhadap pengambilan keputusan pembelian jasa penerbangan

\begin{tabular}{|l|l|l|l|l|l|l|}
\hline \multirow{2}{*}{ Model } & Unstandardized Coefficient & \multicolumn{2}{|c|}{ Standardize Coefficients } & \multirow{2}{*}{$\mathrm{t}$} & \multirow{2}{*}{ Sig. } \\
\cline { 2 - 5 } & & $\mathrm{B}$ & Std. Error & Beta & & \\
\hline 1 & (Constant) & 10.034 & 1.36 & & 7.329 & .000 \\
\hline & PK & .018 & .047 & .018 & .378 & .706 \\
\hline & H & .873 & .238 & .608 & 3.668 & .000 \\
\hline & RP & .017 & .069 & .012 & .246 & .805 \\
\hline & KP & .705 & .047 & .700 & 14.943 & .000 \\
\hline
\end{tabular}

Dependent Variable pengambilan keputusan pembelian jasa penerbangan, Independent Variable.

PK(Persepsi Kualitas), H(Harga ) RP(Reputasi Perusahaan ) dan Kepuasan Pelanggan.

Berdasarkan tabel di atas, menunjukkan persamaan regresi : PKP $=10,034+.018$ PK $0,873 \mathrm{H}+0,17 \mathrm{RP}+.705 \mathrm{KP}$. Persamaan tersebut menunjukkan bahwa variabel persepsi kualitas, harga, reputasi perusahaan dan kepuasan pelanggan mempunyai pengaruh yang positif terhadap pengambilan keputusan pembelian jasa penerbangan. Dari keempat variabel yang lebih berpengaruh terhadap terhadap pengambilan keputusan pembelian jasa penerbangan yaitu variabel Harga.

Tabel 3. Koefisien Korelasi dan Determinasi Variabel persepsi kualitas, harga,reputasi perusahaan dan kepuasan pelanggan terhadap pengambilan keputusan pembelian jasa penerbangan

\begin{tabular}{|c|c|c|c|c|}
\hline Model & $\mathrm{R}$ & $\mathrm{R}$ Square & Adjusted R Square & Std. Error of the Estimate \\
\hline 1 & $.743^{\mathrm{a}}$ & .552049 & .55201 & 1.829 \\
\hline
\end{tabular}


Dependent Variable pengambilan keputusan pembelian jasa penerbangan, Independent Variable.

PK(Persepsi Kualitas), H(Harga ) RP(Reputasi Perusahaan ) dan Kepuasan Pelanggan.

Berdasarkan tabel di atas menunjukkan koefisien korelasi variabel persepsi kualitas, harga, reputasi perusahaan dan kepuasan pelanggan terhadap pengambilan keputusan pembelian jasa penerbangan mempunyai hubungan yang sangat kuat dengan nilai $r=$ .743. Koefisien determinasinya sebesar $\mathrm{r}^{2}=.552049$, artinya variabel Variabel persepsi kualitas ,Harga, Reputasi Perusahaan dan kepuasan pelanggan mampu menjelaskan 55,2 \% terhadap pengambilan keputusan pembelian jasa penerbangan, sedangkan $44,8 \%$ dipengaruhi oleh faktor-faktor lain.

Tabel 4. Nilai F. Hitung Variabel persepsi kualitas, harga, reputasi perusahaan dan kepuasan pelanggan terhadap pengambilan keputusan pembelian jasa penerbangan

\begin{tabular}{|c|c|c|c|c|c|c|}
\hline \multicolumn{2}{|c|}{ Model } & Sum of Squares & df & Mean Square & F & Sig. \\
\hline \multirow{2}{*}{1} & Regression & 190.673 & 1 & 190.673 & 105.067 & $.000^{\mathrm{a}}$ \\
& Residual & 325.483 & 94 & 3.463 & & \\
& Total & 516.156 & 95 & & & \\
\hline
\end{tabular}

Dependent Variable pengambilan keputusan pembelian jasa penerbangan, Independent Variable. Pelanggan.

PK(Persepsi Kualitas), H(Harga ) RP(Reputasi Perusahaan ) dan Kepuasan

Berdasarkan tabel 2, menunjukkan nilai t hitung (Harga dan Kepuasan Pelanggan) $>\mathrm{t}$ tabel artinya secara parsial variabel harga dan kepuasan pelanggan mempunyai pengaruh yang signifikan terhadap pengambilan keputusan pembelian jasa penerbangan. Sedangkan thitung (persepsi kualitas dan reputasi perusahaan) $\leq \mathrm{t}$ tabel secara parsial tidak mempunyai pengaruh yang signifikan terhadap pengambilan keputusan pembelian jasa penerbangan. Berdasarkan tabel 4 menunjukkan bahwa F hitung (Variabel persepsi kualitas, harga, reputasi perusahaan dan kepuasan pelanggan) $>\mathrm{F}$ tabel, artinya secara simultan variabel tersebut mempunyai pengaruh yang signifikan terhadap pengambilan keputusan pembelian jasa penerbangan.

\section{Pembahasan}

Berdasarkan analisis deskriptif dari 96 responden yang diamati, bahwa mahasiswa Unika Santo Thomas SU lebih dominan berasal dari luar Kota Medan . Dari hasil persamaan regresi menunjukkan : PKP $=10,034+.018 \mathrm{PK} 0,873 \mathrm{H}+0,17 \mathrm{RP}+.705 \mathrm{KP}$. Persamaan tersebut menunjukkan bahwa variabel persepsi kualitas, harga, reputasi perusahaan dan kepuasan pelanggan mempunyai pengaruh yang positif terhadap pengambilan keputusan pembelian jasa penerbangan. Dari keempat variabel yang lebih berpengaruh terhadap terhadap pengambilan keputusan pembelian jasa penerbangan yaitu variabel Harga.

Persepsi kualitas (perceived quality) menurut Aaker (1997) dapat didefinisikan sebagai persepsi pelanggan terhadap keseluruhan kualitas atau keunggulan suatu produk atau jasa layanan berkaitan dengan apa yang diharapkan oleh pelanggan. Aaker (1997) menegaskan satu hal yang harus selalu diingat, yaitu bahwa persepsi kualitas merupakan persepsi para pelanggan, oleh sebab itu persepsi kualitas tidak dapat ditetapkan secara obyektif. Selain itu, persepsi pelanggan akan melibatkan apa yang penting bagi pelanggan karena setiap pelanggan memiliki kepentingan yang berbeda-beda terhadap suatu produk atau jasa (Aaker 1997). Maka dapat dikatakan bahwa membahas persepsi kualitas berarti akan membahas keterlibatan dan kepentingan pelanggan. Persepsi kualitas yang tinggi 
menunjukkan bahwa melalui penggunaan dalam jangka waktu yang panjang, konsumen memperoleh diferensiasi dan superioritas dari merek tersebut. Zeithaml mengidentifikasikan persepsi kualitas sebagai komponen dari nilai merek dimana persepsi kualitas yang tinggi akan mengarahkan konsumen untuk memilih merek tersebut dibandingkan dengan merek pesaing. Persepsi kualitas yang dirasakan oleh konsumen berpengaruh terhadap kesediaan konsumen tersebut untuk membeli sebuah produk. Ini berarti bahwa semakin tinggi nilai yang dirasakan oleh konsumen, maka akan semakin tinggi pula kesediaan konsumen tersebut untuk akhirnya membeli (Chapman dan Wahlers, 1999).

Persepsi kualitas (perceived quality) menurut Aaker (1997) dapat didefinisikan sebagai persepsi pelanggan terhadap keseluruhan kualitas atau keunggulan suatu produk atau jasa layanan berkaitan dengan apa yang diharapkan oleh pelanggan. Aaker (1997) menegaskan satu hal yang harus selalu diingat, yaitu bahwa persepsi kualitas merupakan persepsi para pelanggan, oleh sebab itu persepsi kualitas tidak dapat ditetapkan secara obyektif. Selain itu, persepsi pelanggan akan melibatkan apa yang penting bagi pelanggan karena setiap pelanggan memiliki kepentingan yang berbeda-beda terhadap suatu produk atau jasa (Aaker 1997). Maka dapat dikatakan bahwa membahas persepsi kualitas berarti akan membahas keterlibatan dan kepentingan pelanggan. Persepsi kualitas yang tinggi menunjukkan bahwa melalui penggunaan dalam jangka waktu yang panjang, konsumen memperoleh diferensiasi dan superioritas dari merek tersebut. Zeithaml mengidentifikasikan persepsi kualitas sebagai komponen dari nilai merek dimana persepsi kualitas yang tinggi akan mengarahkan konsumen untuk memilih merek tersebut dibandingkan dengan merek pesaing. Persepsi kualitas yang dirasakan oleh konsumen berpengaruh terhadap kesediaan konsumen tersebut untuk membeli sebuah produk. Ini berarti bahwa semakin tinggi nilai yang dirasakan oleh konsumen, maka akan semakin tinggi pula kesediaan konsumen tersebut untuk akhirnya membeli (Chapman dan Wahlers, 1999).

Stedman (2000) mengidentifikasikan bahwa harga merupakan salah satu factor penting yang dapat mempengaruhi perilaku konsumen dalam pembelian merek, karena suatu barang atau jasa pastilah mempunyai nilai. Sedangkan nilai itu sendiri didasarkan dari harga, yang merupakan tolak ukur dari barang maupun jasa yang bersangkutan. Kennedy (1994) mengemukakan bahwa penjualan produk berkualitas tinggi kemungkinan dapat ditandai berdasarkan harga yang tinggi pula. Konsumen seringkali menggunakan harga sebagai petunjuk ekstrinsik atau indikator dari kualitas ataupun manfaat suatu produk. Hasil dari beberapa penelitian mengemukakan bahwa harga yang tinggi dari suatu merek seringkali dipersepsikan memiliki kualitas yang tinggi dan tidak peka terhadap persaingan potongan harga seperti merek-merek dengan harga yang rendah (Yoo, Donthu, dan Lee, 2000). Harga yang tinggi dapat menimbulkan persepsi kualitas produk atau jasa yang tinggi pula dari suatu merek (Monroe, 1973 dalam Ward, Chitty, and Achard, 2005; Dodds, Grewal, dan Monroe, 1991). Dalam penelitiannya, Ward, Chitty, and Achard (2005) mengukur persepsi harga dari konsumen dengan perkiraan besarnya harga yang bersedia dibayar oleh mereka untuk tiap merek terlibat. Teknik tersebut juga digunakan oleh AlSabbahy, Ekinci, dan Riley (2004) menilai persepsi responden terhadap kewajaran harga yang harus dibayar beradasarkan internal feeling dan pengetahuan mereka atas harga dari penyedia jasa lainnya pada bidang yang sama.

Zeithaml (1988) mengemukakan bahwa kualitas yang dirasakan (perceived quality) dari suatu produk atau jasa erat hubungannya dengan reputasi yang diasosiasikan dengan nama merek. Reputasi perusahaan sangat penting dari sudut pandang pelanggan untuk memberikan gambaran terhadap kualitas produk atau jasa yang dihasilkan (Brown dan Dacin, 1997). Herbig, Milewicz dan Golden (1994) menyatakan bahwa reputasi perusahaan dapat dilihat dari kompetensi perusahaan tersebut dan keunggulan dibandingkan dengan 
kompetitornya. Lebih jauh lagi Moorman dan Minner (1997) menyatakan bahwa keahlian perusahaan tercermin dalam pengetahuan dan pengalaman perusahaan tersebut dalam industri yang dimasukinya.

Woodside $(1989,6)$ dkk, kepuasan langganan serta keseluruhan dengan pelayanan merupakan suatu fungsi dari kualitas pelayanan seluruhnya dan keseluruhan kepuasan pelayanan dipengaruhi secara terpisah baik oleh kualitas pelayanan juga oleh kepuasan hidup. Dengan kepuasan pelanggan atas pelayanan secara keseluruhan, yang merupakan fungsi dari kualitas pelayanan akan membuat pelanggan benar-benar merasa puas dan pelanggan yang puas akan memunculkan keinginan untuk terus menjalin hubungan kemitraan (minat untuk membeli ulang). Keinginan tersebut akan muncul apabila terjadi persamaan persepsi antara pelanggan dengan pihak manajemen tentang berbagai faktor yang mempengaruhi kepuasan. Kepuasan pelanggan penting bagi para pemasar karena merupakan determinan dari pembelian ulang (Bearden dan Teel, 1983 dalam Woodside, Frey, dan Daly, 1989). Terdapat hubungan positif secara langsung antara kepuasan pelanggan dengan minat beli ulang yang didukung oleh hasil-hasil penelitian terhadap berbagai kategori produk dan jasa (Anderson dan Sullivan, 1993; Bolton, 1998; Cronin dan Taylor, 1992; Fornell, 1992; Oliver, 1980; Patterson dan Spreng, 1997; Rust dan Zahorik, 1993; Selnes, 1998; Swan dan Trawick, 1981; Taylor dan Baker, 1994; Woodside et al, 1989 dalam Hellier, Geursen, Carr, dan Rickard, 2003). Dengan adanya kepuasan dari pelanggan, maka pelanggan akan memiliki minat untuk menggunakan kembali jasa dari provider yang sama (Hellier, Geursen, Carr, dan Rickard, 2002; Cronin dan Taylor, 1992). Hasil-hasil penelitian tersebut mengemukakan bahwa kepuasan pelanggan secara keseluruhan pada layanan jasa berasosiasi kuat terhadap perilaku konsumen untuk menggunakan kembali jasa dari penyedia yang sama.

\section{KESIMPULAN}

Berdasarkan hasil penelitian dan pembahasan terdapat beberapa kesimpulan :

1. Berdasarkan analisis induktif menunjukkan hasil persamaan regresi : PKP $=10,034+$ $.018 \mathrm{PK} 0,873 \mathrm{H}+0,17 \mathrm{RP}+.705 \mathrm{KP}$. Persamaan tersebut menunjukkan bahwa variabel persepsi kualitas, harga, reputasi perusahaan dan kepuasan pelanggan mempunyai pengaruh yang positif terhadap pengambilan keputusan pembelian jasa penerbangan. Dari keempat variabel yang lebih berpengaruh terhadap terhadap pengambilan keputusan pembelian jasa penerbangan yaitu variabel Harga.

2. Koefisien korelasi variabel persepsi kualitas, harga, reputasi perusahaan dan kepuasan pelanggan terhadap pengambilan keputusan pembelian jasa penerbangan mempunyai hubungan yang sangat kuat dengan nilai $r=.743$. Koefisien determinasinya sebesar $\mathrm{r}^{2}=$ .552049, artinya variabel Variabel persepsi kualitas ,Harga, Reputasi Perusahaan dan kepuasan pelanggan mampu menjelaskan 55,2 \% terhadap pengambilan keputusan pembelian jasa penerbangan, sedangkan $44,8 \%$ dipengaruhi oleh faktor-faktor lain.

3. Berdasarkan Uji $t$, menunjukkan nilai $t$ hitung (Harga dan Kepuasan Pelanggan) $>t$ tabel artinya secara parsial variabel harga dan kepuasan pelanggan mempunyai pengaruh yang signifikan terhadap pengambilan keputusan pembelian jasa penerbangan. Sedangkan $t$ hitung (persepsi kualitas dan reputasi perusahaan) $\leq t$ tabel secara parsial tidak mempunyai pengaruh yang signifikan terhadap pengambilan keputusan pembelian jasa penerbangan. Berdasarkan tabel 5.18 menunjukkan bahwa $\mathrm{F}$ hitung (Variabel persepsi kualitas, harga, reputasi perusahaan dan kepuasan pelanggan) > F tabel, artinya secara simultan variabel tersebut mempunyai pengaruh yang signifikan terhadap pengambilan keputusan pembelian jasa penerbangan.

\section{SARAN}


Persamaan regresi berganda menunjukkan PKP $=10,034+.018$ PK 0,873H + 0,17RP $+.705 \mathrm{KP}$. Artinya bahwa variabel harga dan kepuasan pelanggan mempunyai pengaruh yang lebih dominan terhadap pengambilan keputusan pembelian jasa penerbangan. Sedangkan variabel persepsi kualitas dan reputasi perusahaan pengaruhnya lebih kecil dari pada variabel lainnya. Maka sebaiknya pihak perusahaan perlu meningkatkan persepsi kualitas melalui peningkatan kualitas pelayanan dan reputasi perusahaan melalui peningkatan atribut yang ditawarkan melalui produknya. Kepuasan pelanggan dan harga menjadi pusat perhatian dari pelanggan, maka sebaiknya pihak manajemen tetap mampu untuk mempertahankannya sehingga memiliki daya saing yang sangat tinggi.

\section{DAFTAR PUSTAKA}

Aaker, David A. (1997), Should You Take Your Brand to Where the action is, Harvard Business Review, Vol. 75, Sept/Oct, p.135-143.

Anderson, Eugene W., Claes Fornell, dan Donald R. Lehmann (1994), "Customer Satisfaction, Market Share, and Profitabiliy : Finding from Sweden", Journal of Marketing, Vol. 58, p.53-66.

Chapman, Joe dan Russ Wahlers (1999), “A Revision and Empirical Test of the Extended Price-Perceived Quality Model", Journal of Marketing, p.53- 64.

Cobb-Walgren, Cathy, Cynthia A. Ruble, dan Naveen Donthu (1995), “Brand Equity, Brand Preference and Purchase Intent", Journal of Advertising, 24 (3), p.25-40.

Fornell, Claes (1992), "A National Customer Satisfaction Barometer : The Swedish Experience", Journal of Marketing, Vol. 56, Jan, p.6-21.

Hawkins, Del I., Roger J. Best, dan Kenneth A. Coney (1998), Consumer Behavior :Building Marketing Strategy, Irwin/McGraw-Hill.

Hellier, Phillip K., Gus M. Geursen, Rodney A. Carr, dan John A. Rickard (2003), "Customer Repurchase Intention : A General Structural Equation Model", European Journal of Marketing, Vol. 37/11, p.1762-1800.

Kotler, Philip dan Armstrong, Gary, 2001. Prinsip-prinsip Pemasaran, Jilid 1, Alih Bahasa: Damos Sihombing, Edisi Kedelapan, Jakarta : Erlangga.

Li, Chieh-Lu dan Joohyun Lee (2001), "Dimensions of Service and Their Influence on Intention to Repurchase", Department of Leisure Studies Penn State University.

Parasuraman, A., Valerie A. Zeithaml, dan Leonard L. Berry (1988), “A Multiple Item Scale for Measuring Consumer Perception on Future Research", Journal of Marketing, Vol. 49/1.

Söderlund, Magnus dan Mats Vilgon (1999), "Customer Satisfaction and Links to Customer Profitability : an Empirical Examination of the Association Between Attitudes and Behavior", Working Paper Series in Business Administration, No. 1.

Sugiyono, 2004. Metode Penelitian Bisnis, Cetakan Keenam, Bandung: Alfabeta.

Ward, Steven, William Chitty, dan Brendan Achard (2005), "Brand Equity in an Online World", Journal of Internet Business, Vol. 2 (April).

Zeithaml, V. A. (1988), "Consumer Perceptions of Price, Quality, and Value : A MeansEnd Model and Synthesis of Evidence", Journal of Marketing, Vol. 52, July, p.52-54. 
Zeithaml, V. A. dan Mario Jo Bitner (1996), Service Marketing, McGraw-Hill Companies Inc., New York. 